\title{
COMPARATIVE ANALYSIS OF METHANE CONCENTRATION NEAR THE JUNCTION OF THE LONGWALL AND TOP ROAD
}

\author{
Marian ZMARZŁY \\ KWK „Bzie-Dębina” \\ Paweł TRZASKALIK \\ KWK „Borynia-Zofiówka-Jastrzębie” Ruch „Zofiówka”
}

\begin{abstract}
:
Mining of longwalls ventilated by the "U" method is willingly applied in Polish coal-mines due to low costs of workings maintenance, low costs of ventilation and a lower fire threat because of a limited flow of air through goafs. However, such a way of ventilation may pose an increased risk of methane explosion. For this reason, the " $U$ " ventilation has been limited in longwalls with methane risk. The mining regulations in force provide that ventilation methane-bearing capacity, i.e. the intensity of methane flow into the ventilation air cannot exceed $20 \mathrm{~m}^{3} \mathrm{CH}_{4} / \mathrm{min}$. The regulations also provide that in the event the absolute methane-bearing capacity, i.e. a sum of methane released to the ventilation air and captured by the methane drainage system is higher than $25 \mathrm{~m}^{3} \mathrm{CH}_{4} / \mathrm{min}$ and the " $\mathrm{U}$ " method of ventilation is applied, the effectiveness of methane drainage should be minimum $50 \%$ in relation to the forecast absolute methane-bearing capacity. To streamline the process of ventilation near the junction of the longwall and the gallery carrying off the used air, auxiliary ventilation means are applied, such as a ventilation partition, a ventube - which supplies air without methane or with a low concentration of methane, injectors etc. Application of these means is limited by the cross-section of the heading carrying off the air from the longwall. Deformations of the ventilating roadway, which is usually located in the one-sided vicinity of goafs, may prevent the use of a ventilation partition, which has a negative influence on the conditions of ventilating the junction of the longwall and ventilating roadway. The author of the article also refers to such conditions, presenting average values and maximum concentrations of methane concentrations recorded with four methane concentration sensors, located in the vicinity of the junction of the longwall and ventilating roadway.
\end{abstract}

Key words: process, process management, process improving, quality management methods

\section{INTRODUCTION}

To properly prepare for the mining of a coal seam under methane threat conditions, it is necessary to forecast the methane-bearing capacity of the longwall. Currently the most frequently used forecast in Poland is the one developed in the Central Institute of Mining, in the experimental mine „Barbara” [9]. This method is based on measurements of methane contents in the mined seam and in seams above and below this seam. The methane content of seams in which sample taking is impossible, is defined as approximation or extrapolation. The gas removal zones to be mined, in the cross-section diagonal to the longwall mining direction, have the shape of triangles with a height dependent on the planned length of the longwall and the angle of seams slope. This forecast is used to design ventilation and methane prophylactics for the initial period of longwall mining. In the further period of exploitation, one can clearly observe that the longwall methane-bearing capacity is not consistent with the initial forecast, which is mainly due to insufficient recognition of changes in geological conditions and in the contents of methane in the rock mass. This leads to the necessity of having new, short-term forecasts of methane concentration. Examples of the methods of preparing such forecasts can be found in $[1,2,3,4,10]$.

The Regulation of the Minister of Energy on detailed requirements regarding the maintenance of underground mining plants [13], which is currently binding in Poland, has imposed a constraint on the possibility of ventilating longwalls along the unmined coal, most often referred to as the " $U$ " ventilation method - the maximum value of methane-bearing capacity cannot exceed $20 \mathrm{~m}^{3} / \mathrm{min}$.

The floor rocks of the mined seam contain layers of coal having a thickness of a few to several centimetres, therefore, they are not suitable for mining. During the exploitation, these layers are subject to caving. The air migrating through goafs oxidizes the fine coal, creating a threat of endogenic fires. The stream of air flowing through the 
longwall is reduced so that the zone of air flowing through goafs will be as small as possible. Due to the fact that the concentration of methane in the air flowing from the longwall must be lower than the admissible one, the air is supplied to the longwall outlet by means of a ventube, whose ventilator is located in the working with a flowing stream of air with zero or low contents of methane (Fig. 1).

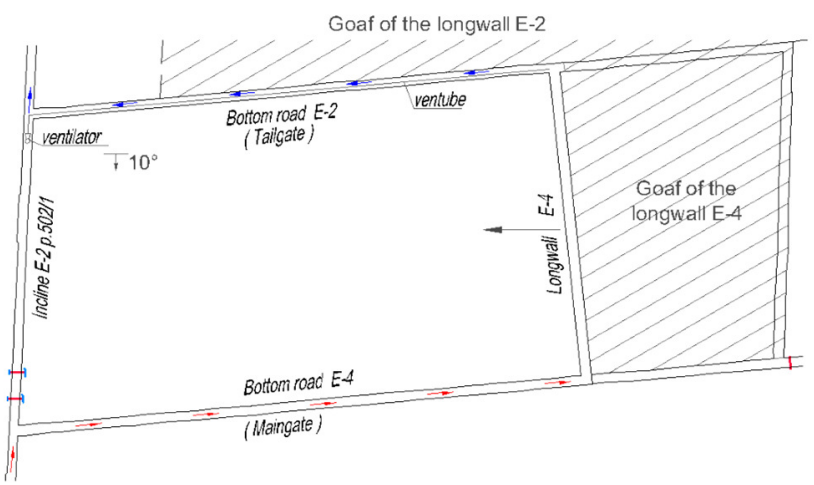

Fig. 1 Working excavation diagram

To limit the concentration of methane in the location of the face conveyor's turning station, a ventilation partition in the ventilating roadway is frequently used at the junction with the longwall [15].

The conditions of methane security are also changed due to deformation of workings, which makes mining and maintaining the proper security conditions difficult [11].

An important role in maintaining safe working conditions under methane threat conditions is played by methane drainage. In Poland we have a lot of experience in this field by using drainage holes and galleries located over the seam being mined. Also methane from goafs of abandoned longwalls is removed $[5,7,14]$. Similarly, all over the world, the removed methane becomes a fuel $[8,16]$, used for the production of heat and power.

Works making use of computational fluid dynamics (CFD) methods are becoming increasingly important in the identification of methane concentration distribution in the ventilation air and longwall goafs. By way of example, in work [6] the influence of locating auxiliary ventilators, installed on the longwall outlet on the possibility of the dissolution and removal of methane from the longwall area was analysed. The efficiency of the designed solution was assessed in a numerical simulation. Calculations were made using FLUENT 6.1 programme.

In work [12] simulation calculations of fluid dynamics (CFD) regarding the dispersion of a methane layer in a ventilating roadway in the ventilated longwall in the " $U$ " system have been presented. In the calculations, a change of air velocity ranging from $0.5 \mathrm{~m} / \mathrm{s}$ to $5 \mathrm{~m} / \mathrm{s}$ were taken into account. It was found that only a speed over $3 \mathrm{~m} / \mathrm{s}$ ensured safe working conditions.

In work [15], using the CFD method, variants of longwall area ventilation with auxiliary ventilating means at the junction of the longwall and the ventilating roadway, as well as without such means, was considered. It was proved that application of auxiliary ventilating means considerably lowers the risk of dangerous methane concentrations.
According to the mining regulations in force, if the forecasted ventilation methane-bearing capacity is higher than $10 \mathrm{~m}^{3} / \mathrm{min}$, the required cross sectional area between the ventilation partition and side-wall opposite the longwall is minimum $6 \mathrm{~m}^{2}$ [13]. This conditions is difficult to fulfil as the longwall panel in located in the vicinity of goafs formed during the exploitation of the neighbouring longwall. For this reasons, mining without a partition as an auxiliary ventilation means are used more and more frequently.

In the article, a comparative analysis of indications of methane monitoring sensors located in the area of the junction of E-4 longwall in seam 505/1 with the ventilating roadway named bottom road of E-2 longwall, at „BoryniaZofiówka-Jastrzębie” Ruch „Zofiówka” coal-mine.

\section{GEOLOGICAL AND MINING CONDIITONS OF E-4 LONGWALL IN SEAM 505/1}

Seam 505/1 in the area of the mine section of E-4 longwall had a thickness ranging from $2.85 \mathrm{~m}$ (locally $2.6 \mathrm{~m}$ ) to 4.15 $\mathrm{m}$.

In the roof (up to ca $60 \mathrm{~m}$ ), the basic part were sandstones (ca 90\%), with thin layers of mudstones and sandy shales, as well as thin layers of coal.

In the floor pack of the seam there were layers of mudstones and sandy shales and seam 505/2, the thickness of which changed considerably. Below these layers the was sandstone.

The wall length ranged from $212 \mathrm{~m}$ to $217 \mathrm{~m}$, and the panel length was approximately $425 \mathrm{~m}$. The height of the longwall was changeable, ranging from $2.9 \mathrm{~m}$ to $3.7 \mathrm{~m}$.

The longitudinal slope of the longwall ranged from $16^{\circ}$ to $19^{\circ}$, and its transverse slope ranged from $-5^{\circ}$ to $3^{\circ}$.

Mining in the closest seams was carried out in seam 502/1 in a verticial distance of ca $90 \mathrm{~m}$ and in seam 418/1-2 in a vertical distance of ca $160 \mathrm{~m}$. The thickness of seams 502/1 and 418/1-2 ranged from $2.5 \mathrm{~m}$ to $2.7 \mathrm{~m}$.

A diagram of the working excavation is presented in Fig. 1. Bottom roads ran from incline $E-2$. The top road was named "bottom road E-2", and the bottom road - "bottom road E-4". Mining was commenced from raise E-4a and carried out from north to south, towards incline E-2. In the area of the designed longwall E-4, the following threats were identified:

1) methane risk: IV category,

2) coal dust explosion risk: class $B$,

3) fire risk: II self-ignitability group,

4) water risk: I degree,

5) rock burst risk: I degree,

6) gas and rock outburst risk: no risk.

The forecasted absolute methane-bearing capacity of the longwall for methane-bearing capacity $400 \mathrm{t} /$ day was 13 $\mathrm{m}^{3} \mathrm{CH}_{4} / \mathrm{min}$. In the process of mining, methane drainage was carried out from the $124^{\text {th }}$ day of exploitation until its end. The location of methane sensors in the longwall area has been presented in Fig. 2 . 


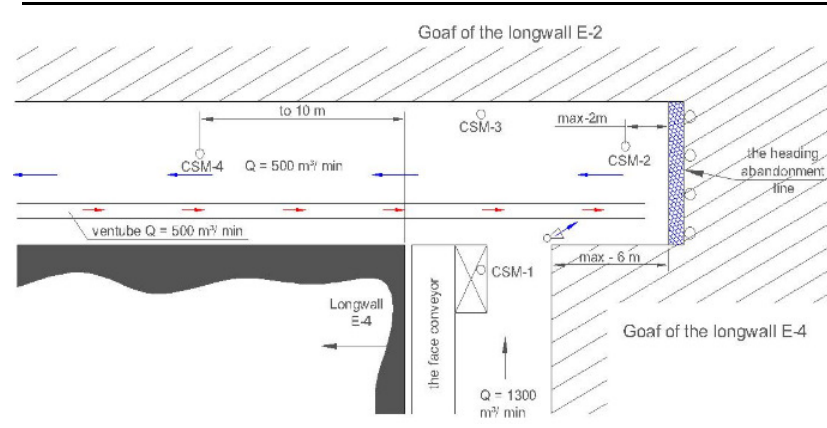

Fig. 2 Site plan of the junction of E-4 longwall with bottom road E-2

Air, in the amount of $1300 \mathrm{~m}^{3} / \mathrm{min}$, was supplied to the longwall from opening-out headings on the level of $900 \mathrm{~m}$ by means of incline $\mathrm{E}-2$, and next through bottom road E-4.

To the junction of the longwall with bottom road E-2 the air - in the amount of ca $500 \mathrm{~m}^{3} / \mathrm{min}$ was supplied by means of a ventube, in order to reduce the methane risk. The ventilator pumping the air with a ventube was located in incline E-2 (Fig. 1).

The air from the wall was carried off through bottom road $\mathrm{E}-2$ to incline $\mathrm{E}-2$, and next, to headings connected with opening-out headings on the level of $705 \mathrm{~m}$.

\section{VENTILATION CONDITIONS AND METHANE CONCENTRA- TION IN THE AREA OF THE JUNCTION OF LONGWALL E-4 WITH BOTTOM ROAD E2}

The location of methane monitoring sensors in the area of the junction of longwall E-4 with bottom road E-2, which carries off the used air from the longwall, has been presented in the diagram contained in Fig. 2. In the further part of the article, this heading will be referred to as the ventilation roadway. The location of methane monitoring sensors complied with the mining regulations to be observed in Polish coal mines.

The sensor marked as CSM-1 was located in the longwall, in the vicinity of the face conveyor's turning station. This sensor was placed no lower than $10 \mathrm{~cm}$ under the powered support roof-bar. CSM-2 sensor was located in a distance of up to $2 \mathrm{~m}$ away from the heading abandonment line. The distance of the heading abandonment line from the roof fall line was changeable, but no bigger than $6 \mathrm{~m}$. The sensor was placed no lower than $10 \mathrm{~cm}$ under the road support roof-bar, at its highest point. The sensor marked as CSM-3 was located on the sidewall of the ventilating roadway, opposite the longwall outlet. CSM-4 sensor was located in the ventilating roadway, within a distance of up to $10 \mathrm{~m}$ away from the longwall line. This sensor was placed no lower than $10 \mathrm{~cm}$ under the road support roof-bar, at its highest point.

Maximum admissible concentration in the locations of sensors is $2 \%$. All the sensors were equipped with the function of deenergizing the electrical equipment in the ventilating roadway, in the longwall and in the heading that supplies air to the longwall over a distance no shorter than $10 \mathrm{~m}$ away from the longwall inlet.

Methane concentration in the area of the junction was monitored in the period between 24.01.2018 and 30.09.2018, which is 250 days. The measurement day started at 6:00:00 and finished at 5:59:59 on the following day. Below have been presented graphs of methane concentration in the abovementioned period (Figs. 3 to 6).

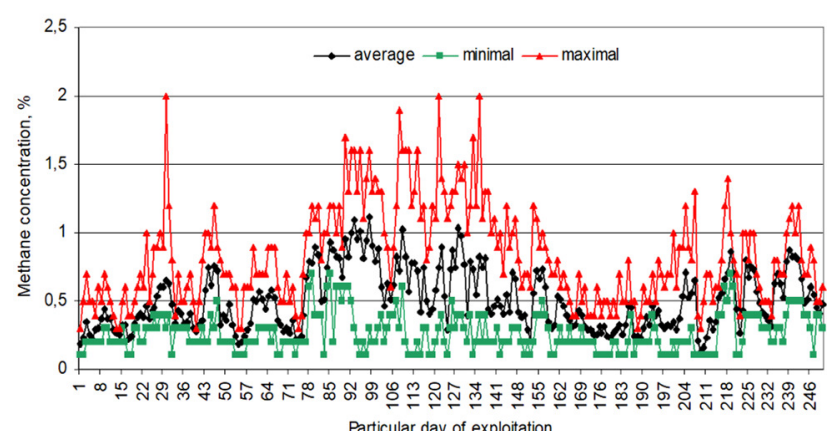

Fig. 3 Methane concentration in the longwall in the area of face conveyor's turning station

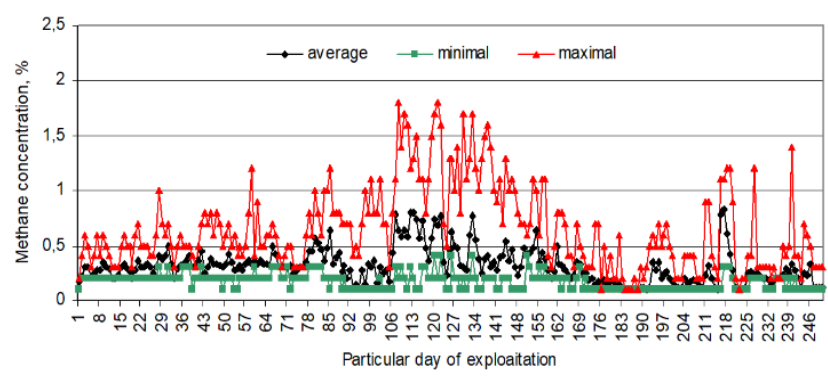

Fig. 4 Methane concentration in the ventilating roadway within a distance of up to $2 \mathrm{~m}$ away from the heading abandonment line

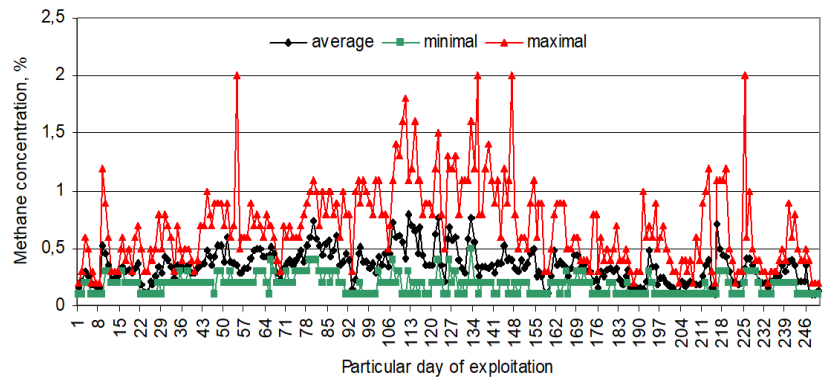

Fig. 5 Methane concentration in the ventilating roadway opposite the longwall outlet

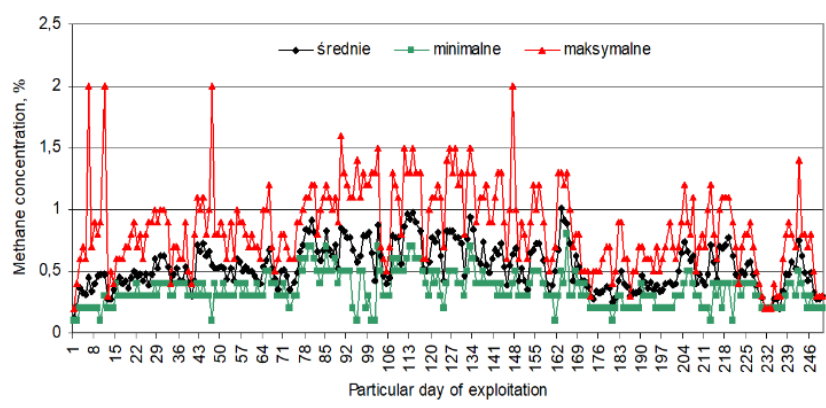

Fig. 6 Methane concentration in the opposite ventilating roadway within a distance of up to $10 \mathrm{~m}$ from the face

The presented graphs (Figs. 3 to 6 ) indicate that methane concentration in the discussed measurement points differed on particular day. Below have been presented tables containing statistical parameters for average values and maximum methane concentrations throughout the exploitation period. 
Table 1

Statistical parameters of the average methane concentration throughout the exploitation period

Location of methane concentration sensor

\begin{tabular}{|c|c|c|c|c|}
\hline $\begin{array}{c}\text { Location of } \\
\text { sensors }\end{array}$ & 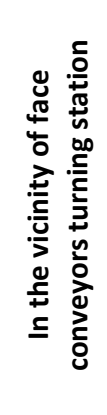 & 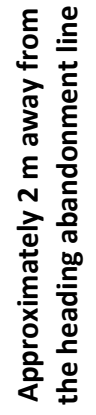 & 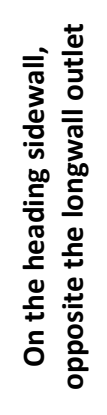 & 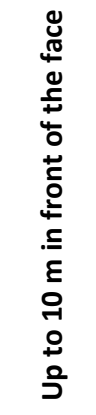 \\
\hline Sensor No. & 1 & 2 & 3 & 4 \\
\hline Average & 0.51 & 0.32 & 0.35 & 0.53 \\
\hline Median & 0.45 & 0.30 & 0.34 & 0.50 \\
\hline $\begin{array}{l}\text { Percentile } \\
0.90\end{array}$ & 0.82 & 0.52 & 0.53 & 0.79 \\
\hline $\begin{array}{l}\text { Standard } \\
\text { deviation }\end{array}$ & 0.22 & 0.16 & 0.14 & 0.18 \\
\hline $\begin{array}{l}\text { Coefficient } \\
\text { of variation }\end{array}$ & 0.43 & 0.50 & 0.41 & 0.33 \\
\hline Range & 0.99 & 0.73 & 0.69 & 0.88 \\
\hline Minimum & 0.13 & 0.10 & 0.10 & 0.13 \\
\hline Maximum & 1.12 & 0.83 & 0.79 & 1.01 \\
\hline Total & 126.57 & 78.87 & 86.62 & 133.52 \\
\hline
\end{tabular}

The highest average concentration, reaching $0.53 \%$ (average value of methane concentration mean daily values) was observed in the case of the sensor located within a distance of up to $10 \mathrm{~m}$ in front of the face. Almost the same high methane concentration, reaching $0.51 \%$, was indicated by the sensor located in the vicinity of the face conveyor's turning station. On the other hand, much lower average concentrations of methane were observed on the heading sidewall, opposite the longwall outlet $(0.35 \%)$ and within a distance of ca $2 \mathrm{~m}$ from the heading abandonment line $(0.32 \%)$.

Taking into account, the values of medians, it can be stated that they ranked the sensors in the same order. This means that for $50 \%$ of exploitation days the values of average methane concentrations recorded with sensor CSM-4 were no lower than $0.50 \%$, the ones recorded with sensor CSM-1 were no lower than $0.45 \%$, with sensor CSM-3 - no lower than $0.35 \%$, and with sensor CSM-2 no lower than $0.30 \%$.

The ranking of sensors is slightly different if we take into consideration the value of concentration which was exceeded in the case of $10 \%$ of measurements (parameter percentile 90). The highest value of percentile 90 was noted for concentrations indicated by sensor CSM-1 $\left(0.82 \% \mathrm{CH}_{4}\right)$, a slightly lower value was recorded with sensor CSM-4 $\left(0.72 \% \mathrm{CH}_{4}\right)$, followed by sensor CSM-3 $(0.53 \%$ $\left.\mathrm{CH}_{4}\right)$ and $\mathrm{CSM}-2\left(0.53 \% \mathrm{CH}_{4}\right)$.

With regard to the maximum average concentration, sensor CSM-1 $\left(1.12 \% \mathrm{CH}_{4}\right)$ is in the first place; the second sensor CSM-4 $\left(1.01 \% \mathrm{CH}_{4}\right)$, the third - CSM-2 $\left(0.83 \% \mathrm{CH}_{4}\right)$, and the fourth place - sensor CSM-3 $\left(0.79 \% \mathrm{CH}_{4}\right)$.
If we take into consideration the value of percentile 90 and maximum average methane concentration simultaneously, we find that for 25 days throughout the exploitation period, the average methane concentration in the vicinity of the face conveyor's turning station ranged from $0.82 \%$ to $1.12 \%$; within a distance of up to $2 \mathrm{~m}$ from the top road abandonment line it ranged from $0.52 \%$ to $0.82 \%$; near the top gate sidewall, opposite the longwall outlet - from 0.53 to $0.79 \%$, and in the sensor location within a distance of up to $10 \mathrm{~m}$ away from the face towards the air flow - from $0.79 \%$ to $1.01 \%$. The presented analysis indicates that the 10-percent range of the highest average methane concentrations was observed in the vicinity of the face conveyor's turning station.

Apart from the values of statistical parameters characterizing the concentration of methane, equally important are parameters that characterize methane concentration fluctuations. These include first of all the coefficient of variation and the range. The coefficient of variation is a quotient of standard deviation divided by the value of average methane concentration, and the range is a difference between the maximum and minimum value of methane concentration.

The highest coefficient of variation was found in the case of sensor CSM-2, located approximately $2 \mathrm{~m}$ away from the top gate abandonment line -0.50 . It results mainly from the changeability of sensor location in relation to the outlet from the ventube supplying fresh air to the part of top gate behind the roof fall line in the longwall, which, in turn, was conditioned by the abandonment of the heading and shortening the ventube. The range is $0.69 \% \mathrm{CH}_{4}$ and it is the lowest of all the considered values.

The second highest value of the coefficient of variation was noted in the case of sensor CSM-1-0.43. Big variations of the average methane concentration in the vicinity of the face conveyor's turning station are indicated by the value of the range, reaching $0.99 \% \mathrm{CH}_{4}$. It is the biggest of the considered ranges. This means that methane concentrations variations were significant.

The third highest value of the coefficient of variation was recorded in the case of sensor CSM-3. This sensor, located opposite the longwall, was supplied with air from both the longwall and the abandoned part of the heading. The coefficient of variation is 0.41 , the range of $0.69 \% \mathrm{CH}_{4}$, i.e.. the variation of average methane concentration in the sensor location was quite high.

The lowest value of the coefficient of variation of methane concentration, reaching 0.33 , was indicated by sensor CSM-4. The range of methane concentration is considerable $-0.88 \% \mathrm{CH}_{4}$. This means that methane concentration fluctuations were significant and there were frequent spikes of high methane concentrations.

In terms of the total mean methane concentration throughout the exploitation period, the order of sensors is consistent with the order of mean concentration, which of course results from the fact that the value of average concentration over the whole period is obtained by dividing the sum of mean concentrations throughout the exploitation period by the number of days in that period. 
An explosion of methane is the most likely to occur in the vicinity of the face conveyor's turning station. This is due mainly to the possibility of the cutting drum's impact against the steel elements of the road support. The uplift of the floor in the road makes a part of the sidewall arch of the road support invisible. An impact of the cutting drum element against the steel support can make a spark that triggers methane explosion. The same effects may be caused by the catching of the road support steel mesh by the cutting drum and its friction against the elements of the mining machine or face conveyor. Of course, the probability of such incidents is very low, but it does exist.

Taking into consideration the high value of average methane concentrations, medians, percentile 90, methane concentration and the highest maximum value accompanied by the highest likelihood of initiating an explosion, we consider the area in the vicinity of the face conveyor's turning station as the most dangerous with regard to methane explosion risk.

Figs. 7 to 10 present the graphs of average methane concentrations, allowing for a comparison of methane concentration mean values resulting from the measurements taken with particular pairs of sensors.

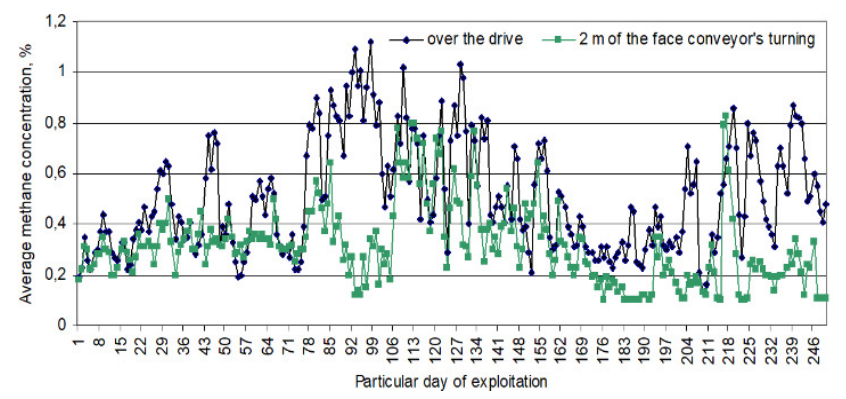

Fig. 7 Graph of the average methane concentration in the vicinity of the face conveyor's turning station (marking: over the drive) and in the vicinity of the top road abandonment line

The graph of methane concentrations contained in Fig. 7 indicates that the average concentration of methane in the vicinity of the face conveyor's turning station in a few periods was considerably higher than the average methane concentration in the vicinity of the top road abandonment line. This is particularly visible in the periods between the eighty fourth and one hundred third day as well as between the two hundred first and two hundred fiftieth day of exploitation. Between the values of average methane concentration in these places, throughout the exploitation period, the correlation is moderate [5], and the correlation coefficient reaches 0.41 . This might be caused by the fact that a part of the heading between the roof fall line behind the longwall and the road abandonment line is ventilated, mainly with a stream of air supplied by the ventube (ca $500 \mathrm{~m}^{3} / \mathrm{min}$ ).

The course of average methane concentration graphs in Fig. 8 is very similar to those in Fig. 7. There are visible periods of strong inconsistencies of the average methane concentrations near the sidewall, opposite the longwall outlet and in the vicinity of the face conveyor's turning station, and periods of their occurrence nearly overlap with the periods of inconsistencies in Fig. 7. The correlation coefficient between the mean values of methane concentrations in the discussed places is $r=0.50$ (moderate correlation [17]).

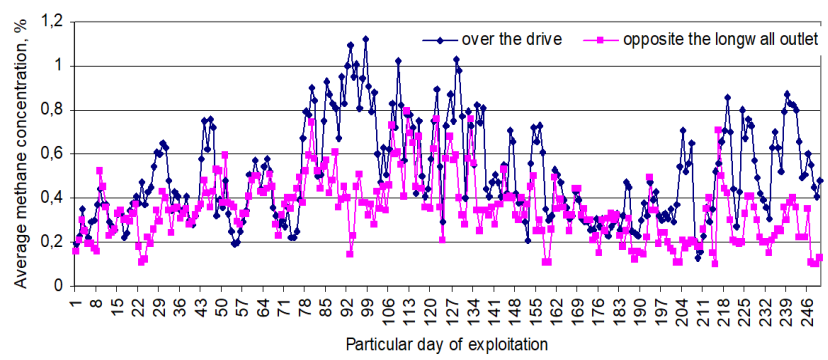

Fig. 8 Graph of the average methane concentration in the vicinity of the face conveyor's turning station (marking: over the drive) and in the vicinity of the top road sidewall, opposite the longwall outlet

Fig. 9 presents graphs of average concentration in the vicinity of the top road abandonment line and on the road sidewall, opposite the longwall outlet.

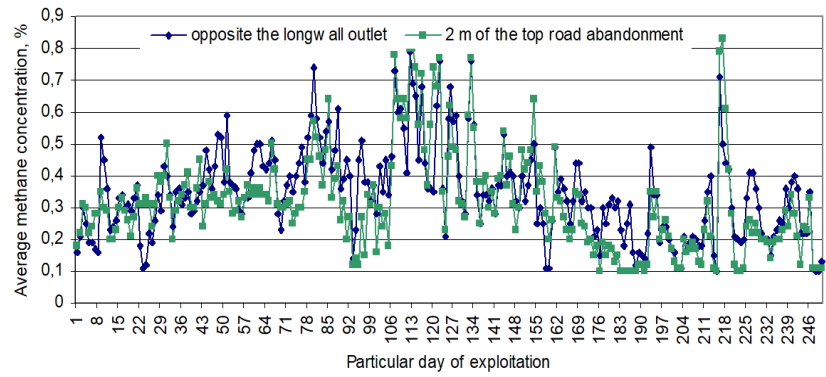

Fig. 9 Graph of average methane concentration in the vicinity of the top road abandonment line and near the top road sidewall, opposite the longwall outlet

The course of graphs in the drawing shows a considerable inconsistency between the values and tendencies of average concentration changes in the discussed places. The value of correlation coefficient is $=0.81$ [17].

The quoted observations indicate that the air current under the road sidewall, at the point of sensor location, was ventilated mainly with a current of air supplied by the ventube.

Fig. 10 refers to measurements in the longwall, in the vicinity of the face conveyor's turning station and in the top road, within a distance of up to $10 \mathrm{~m}$ away from the face. There is a strong resemblance between graphs presenting the course of average methane concentration in these places. In terms of quality, the graphs are very similar. This means that both the values of methane concentration and the nature of concentration changes are alike. The coefficient of correlation between average methane concentrations in the aforesaid places is $r=0.65$, which proves a moderate dependence between them [17].

The nature and value of methane concentration changes at the location of sensor CSM-4 is influenced by the composition of the stream of air supplied from the longwall as well as from the top road abandonment side. Fig. 11 presents graphs of average methane concentration based on measurements with sensors CSM-3 and CSM-4. 


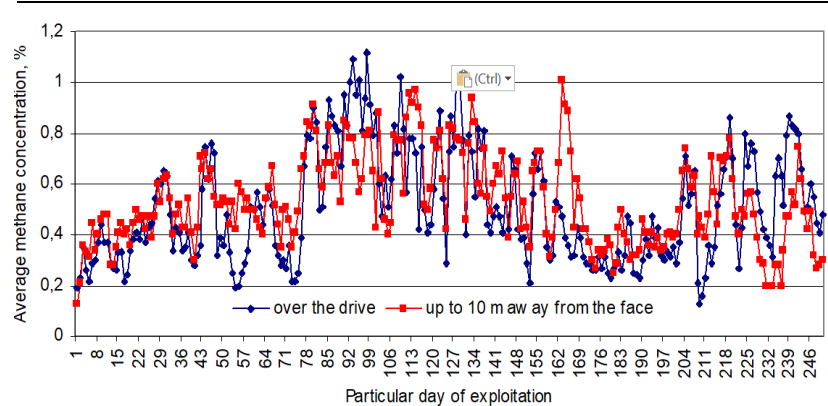

Fig. 10 Graph of average methane concentration in the vicinity of the face conveyor's turning station and within a distance of up to $10 \mathrm{~m}$ away from the face

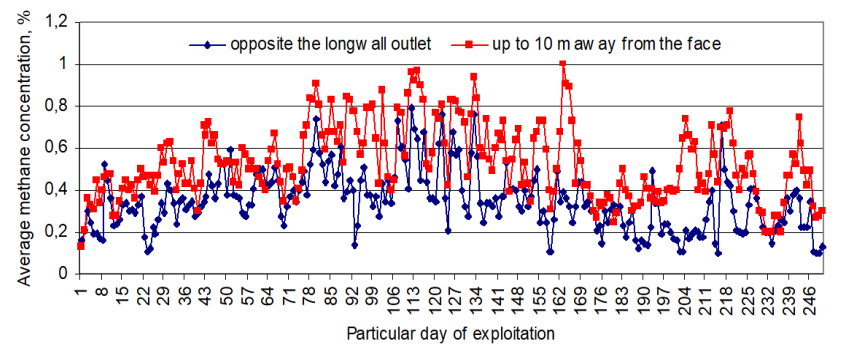

Fig. 11 Graph of average methane concentration near the top road sidewall, opposite the longwall outlet and within a distance of up to $10 \mathrm{~m}$ away from the face

The value of the coefficient of correlation between average concentrations in aforesaid places is $r=0.63$, therefore, it is lower than the correlation coefficient between indications of sensors CSM- 1 and CSM- 4 only by 0.02 .

Table 2 contains values of the coefficients of correlation between average methane concentrations calculated on the basis of particular sensors' indications.

Table 2

Average methane concentration correlation coefficients

\begin{tabular}{ccccc} 
Sensor & CSM-1 & CSM-2 & CSM-3 & CSM-4 \\
\hline CSM-1 & - & 0.41 & 0.50 & 0.65 \\
CSM-2 & 0.41 & - & 0.81 & 0.61 \\
CSM-3 & 0.50 & 0.81 & - & 0.63 \\
CSM-4 & 0.65 & 0.61 & 0.63 & - \\
\hline
\end{tabular}

Table 3 presents descriptive statistics on the maximum concentrations of methane on particular days, measured with appropriate sensors.

The highest mean value of maximum methane concentration was recorded by the sensor located within a distance of up to $10 \mathrm{~m}$ away from the face (CSM-4) $0.86 \% \mathrm{CH}_{4}$. The second highest value was noted in the vicinity of the face conveyor's turning station (CSM-1).

Percentile 90 does not differ significantly and reaches 1.3\% $\mathrm{CH}_{4}$ for sensors CSM-1 and CSM-4, and $1.2 \% \mathrm{CH}_{4}$ and $1.1 \% \mathrm{CH}_{4}$ for sensors CSM-2 and CSM-3, respectively. The highest value of the variation coefficient was observed in the case of the maximum methane concentration in the vicinity of the top road abandonment line $(0.58$, sensor CSM-2), and the lowest at the location of sensor CSM-4 (0.39).
Table 3

Statistical parameters of the maximum concentration of methane throughout the exploitation period Location of methane concentration sensor

\begin{tabular}{|c|c|c|c|}
\hline $\begin{array}{l}\text { Statistical } \\
\text { parameter }\end{array}$ & 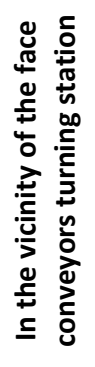 & 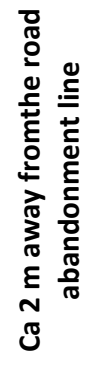 & 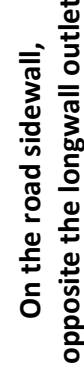 \\
\hline
\end{tabular}

\begin{tabular}{lcccc}
\hline Sensor No. & 1 & 2 & 3 & 4 \\
Average & 0.84 & 0.65 & 0.70 & 0.86 \\
Median & 0.8 & 0.6 & 0.6 & 0.8 \\
$\begin{array}{l}\text { Percentile } \\
90\end{array}$ & 1.3 & 1.2 & 1.1 & 1.3 \\
$\begin{array}{l}\text { Standard } \\
\text { deviation }\end{array}$ & 0.36 & 0.38 & 0.36 & 0.33 \\
$\begin{array}{l}\text { Coefficient } \\
\text { of variation }\end{array}$ & 0.43 & 0.58 & 0.52 & 0.39 \\
$\begin{array}{l}\text { Range } \\
\text { Minimum }\end{array}$ & 1.7 & 1.7 & 1.8 & 1.8 \\
Maximum & 0.3 & 0.1 & 0.2 & 0.2 \\
Total & 2.0 & 1.8 & 2.0 & 2.0 \\
\hline
\end{tabular}

Sensors CSM-1, CSM-3 and CSM- 4 indicated a maximum methane concentration of $2 \%$; it is worth mentioning that sensor CSM-1 recorded three such cases, 2\%, CSM-3- 4 cases, and CSM-4 - 3 cases.

The exceeding of methane concentration in the vicinity of the face conveyor's turning station did not cause the exceeding in the location of the sensor within a distance of up to $10 \mathrm{~m}$ away from the longwall. There was one case of exceeding the concentration $2 \% \mathrm{CH}_{4}$, opposite the longwall outlet and in the location of the sensor in front of the longwall. There was also only one case of exceeding the admissible concentration in the vicinity of the face conveyor's turning station and near the road sidewall, opposite the longwall outlet.

The sum of maximum methane concentrations was the highest for the sensor located within a distance of up to $10 \mathrm{~m}$ away from the longwall (CSM-4 $\left.-214.5 \% \mathrm{CH}_{4}\right)$, and slightly lower for the sensor in the vicinity of the face conveyor's turning station CSM-1 $-209 \% \mathrm{CH}_{4}$.

The coefficients of correlation between maximum values of methane concentration have been given in Table 4 .

Table 4

Coefficients of correlation of maximum methane

\begin{tabular}{ccccc} 
& & & \multicolumn{2}{c}{ concentration } \\
\hline Sensor & CSM-1 & CSM-2 & CSM-3 & CSM-4 \\
\hline CSM-1 & - & 0.70 & 0.63 & 0.62 \\
CSM-2 & 0.70 & - & 0.75 & 0.57 \\
CSM-3 & 0.63 & 0.75 & - & 0.60 \\
CSM-4 & 0.62 & 0.57 & 0.60 & - \\
\hline
\end{tabular}


Due to the highest probability of initiating an explosion as well as high average and maximum concentrations of methane and high percentile 90, the greatest likelihood of methane explosion was in the conveyor's turning station. Of course, given the values of percentile 90 of the average and maximum methane concentration and the number of cases when the concentration of $2 \% \mathrm{CH}_{4}$ was exceeded, this probability was very small.

\section{FINDINGS AND CONCLUSIONS}

Longwall E-4 in seam 505/1 in "Zofiówka" coal-mine was ventilated using the " $U$ " method. In the vicinity of the longwall outlet, auxiliary ventilation with a ventube was carried out for a part of the top road behind the roof fall line in the longwall. A ventilation partition was not used. The applied method of ventilation, in accordance with [13], requires using minimum four sensors of methane concentration near the longwall outlet.

The analysis of methane risk was based on the values of average and maximum methane concentrations on a particular day, calculated on the basis of each sensor's indications. The methane concentration analysis was carried out for the whole period of longwall exploitation, i.e. 250 days.

The conducted analysis allows formulating the following conclusions:

1. A comparison of average methane concentrations calculated for the whole period of exploitation indicates that the highest concentration was noted in the location of the sensor within a distance of up to $10 \mathrm{~m}$ away from the face $\left(0.53 \% \mathrm{CH}_{4}\right)$. A slightly lower concentration of methane was recorded in the vicinity of the face conveyor's turning station $\left(0.51 \% \mathrm{CH}_{4}\right)$, whereas the lowest value of average methane concentration was noted in the location of the sensor approximately $2 \mathrm{~m}$ away from the road roof fall line (0.32\%).

2. The coefficient of variation of average methane concentration within a distance of up to $10 \mathrm{~m}$ away from the longwall was the lowest, reaching 0.33 . In the vicinity of the turning station, its value was relatively high -0.43 , whereas the highest value of this parameter was noted in the case of average methane concentration near the top road abandonment line (0.50).

3. Ten percent of the average values of methane concentration in the vicinity of the conveyor's turning station ranged from $0.82 \% \mathrm{CH}_{4}$ to $1.12 \% \mathrm{CH}_{4}$, and within a distance of up to $10 \mathrm{~m}$ away from the longwall, it ranged from $0.79 \% \mathrm{CH}_{4}$ to $1.01 \% \mathrm{CH}_{4}$.

4. The sensor located within a distance of up to $2 \mathrm{~m}$ away from the roof fall line did not indicate the exceeding of the maximum methane concentration $2 \% \mathrm{CH}_{4}$. There were three cases of exceeding the admissible value in the vicinity of the conveyor's turning station as well as four such cases recorded near the heading sidewall, opposite the longwall outlet, and within a distance of up to $10 \mathrm{~m}$ away from the longwall.

5. Ten percent of maximum values of methane concentration in the vicinity of the conveyor's turning station and within a distance of up to $10 \mathrm{~m}$ away from the longwall ranged from $1.3 \% \mathrm{CH}_{4}$ to $2 \% \mathrm{CH}_{4}$.

6. A comparison of average methane concentration graphs, regarding particular methane concentration sensors indicates that despite slight distances between the sensors, the values of average methane concentration differ considerably. The same conclusion results from the analysis of maximum methane concentration distribution.

7. The coefficients of correlation between the average values of methane concentration at measurement points range from 0.41 to 0.81 . The highest correlation is observed between measurements indicated by sensors CSM-2 and CSM-3, i.e., within a distnace of ca $2 \mathrm{~m}$ away from the roof fall line in the heading and near the heading sidewall, opposite the longwall outlet. This is caused by the fact that the air in the existing part of the heading is the main part of air stream in the location of the sensor near the heading sidewall, opposite the longwall outlet.

8. The lowest value of the coefficient of correlation between average methane concentration values was recorded by sensor CSM-1, in the vicinity of the face conveyor's turning station and by sensor CSM-2, located within a distance of ca $2 \mathrm{~m}$ away from the heading roof fall line.

9. The similar values of the correlation coefficient between average methane concentration recorded by sensor CSM-4, located $10 \mathrm{~m}$ away from the face, and the remaining sensors indicates that methane is largely mixed with the ventilation air. The lowest coefficient of correlation is observed between methane concentrations recorded in locations which are the furthest from each other $(0.61$ - sensor CSM-2 and CSM-4), and the highest, reaching 0.65 , between methane concentrations in the vicinity of face conveyor's turning station (sensor CSM-1) and sensor CSM-4.

10. The coefficients of correlation between maximum methane concentrations indicated by particular sensors range from 0.57 to 0.75 . The highest correlation coefficient regards sensors CSM-2 and CSM-3. This confirms the conclusion contained in point 7.

11. The lowest coefficient of correlation is observed between maximum methane concentrations recorded by sensors CSM- 2 and CSM-4, which confirms the conclusion contained in point 9.

12. A comparison of statistical indications of the average and maximum methane concentration and the possibility of initiating an explosion allow concluding that an explosion was the most likely to occur in the area near the conveyor's turning station, but this probability was very low.

\section{REFERENCES}

[1] Badura H.: Analiza wpływu niektórych czynników na metanowość rejonu ściany D-2 w pokładzie 409/4 w KWK „R". Przeglqd Górniczy nr 4, Katowice 2007.

[2] Badura H.: Analiza stężeń metanu na wylocie z rejonu ściany P-4 w KWK „R”. Górnictwo i Geologia. Kwartalnik t. 2, z. 2. Wydawnictwo Politechniki Śląskiej, Gliwice 2007. 
[3] Badura H.: Badanie średnich i maksymalnych dobowych stężeń metanu w rejonie ściany D-33 w KWK „Borynia” Górnictwo i Geologia. Kwartalnik, z. 3, t. 4. Wydawnictwo Politechniki Śląskiej, Gliwice 2009.

[4] Badura H.: Metody prognoz krótkoterminowych stężenia metanu na wylotach z rejonów ścian zawałowych w kopalniach węgla kamiennego. Monografia. Wyd. Politechniki Śląskiej, 2013

[5] Berger J., Markiewicz J., Badylak A.: Odmetanowanie kluczem do poprawy bezpieczeństwa i efektywności eksploatacji ścianowej w kopalniach węgla kamiennego. Metan i jego wykorzystanie - Materiały Szkoły Eksploatacji Podziemnej, Kraków 2011, pp. 75-83

[6] Branny, M. Computer simulation of flow of air and methane mixture in the longwall-return crossing zone. Archives of Mining Sciences, 51, 2006, pp.133-145.

[7] Jakubów A.: Doświadczenia w odmetanowaniu kopalń Jastrzębskiej Spółki Węglowej S.A. Pozyskiwanie i utylizacja metanu z pokładów węgla - Materiały konferencyjne. Jastrzębie-Zdrój 15-16 maja 2014 r.

[8] Karacan C.Ö., Ruiz F.A., Cote m., Phipps S.: Coal mine methane: A review of capture and utilization practices with benefits to mining safety and greenhouse gas reduction. International Journal of Coal Geology. No 86, 2011, pp. 121-156

[9] Krause E., Łukowicz K.: Dynamiczna prognoza metanowości bezwzględnej ścian. Poradnik techniczny. Główny Instytut Górnictwa, Kopania Doświadczalna „Barbara”. Katowice-Mikołów. 2000.

\section{Marian Zmarzły}

KWK „Bzie-Dębina” in construction

ul. Górnicza 1, 44-330 Jastrzębie-Zdrój, Poland

e-mail:ma.z@o2.pl

ORCID ID: 0000-0003-2450-0264

\section{Paweł Trzaskalik}

KWK „Borynia-Zofiówka-Jastrzębie” Ruch „Zofiówka”

ul. Węglowa 4, 44-268 Jastrzębie-Zdrój, Poland

e-mail: ptrzaskalik@o2.pl

ORCID ID: 0000-0002-5921-0948
[10] Krause E. 2015: Short-Term Predictions of Methane Emissions During Longwall Mining. Archives of Mining Sciences, Vol. 60, No 2, 2015, pp 581-594.

[11] Krause, E.; Wierzbiński, K. Wpływ przekrojów wyrobisk oraz uwarunkowań wentylacyjno-metanowych w środowisku ścian na kształtowanie się zagrożenia metanowego. Przeglqad Górniczy 2009, t. 65, str. 52-60.

[12] Mishra, D.P., Kumar, P., Panigrahi, D.C.: Dispersion of methane in tailgate of a retreating longwall mine: A computational fluid dynamics study. Environ. Earth Sci. 75, 2016, 475.

[13] Rozporządzenie Ministra Energii w sprawie szczegółowych wymagań dotyczących prowadzenia ruchu podziemnych zakładów górniczych. Dz. U. z dnia 9 czerwca 2017 r., poz. 1118.

[14] Szlązak N., Obracaj D., Swolkień J. Methane Drainage from Roof Strata Using and Overlying Drainage Galery. International Journal of Coal Geology, No 136, 2014, pp. 99-115

[15] Tutak M., Brodny J.: Analysis of the Impact of Auxiliary Ventilation Equipment on the Distribution and Concentration of Methane in the Tailgate. Energies No 11, 2018 3076.

[16] Uszko M., Kloc L., Szarafiński M., Potoczek H.: Pozyskiwanie i zagospodarowanie metanu z odmetanowania kopalń Kompanii Węglowej S.A. Pozyskiwanie i utylizacja metanu z pokładów węgla - materiały konferencyjne. JastrzębieZdrój, 16 maja 2014 r., pp. 185-196.

[17] Zeliaś A.: Metody statystyczne. Polskie Wydawnictwo Ekonomiczne. Warszawa. $2000 \mathrm{r}$. 